doi:10.5559/di.21.3.12

\section{Ines Kersan-škabić EKONOMIJA EUROPSKE UNIJE}

Sveučilište Jurja Dobrile u Puli, Odjel za ekonomiju i turizam "Dr. Mijo Mirković", Pula, 2012., 393 str.

Politička "hegemonija" Europske unije (EU) na prostoru Europe, pa i šire, nije samo odraz političkih, ekonomskih, društvenih, kulturnih i religijskih ideja o zajedništvu, koordinaciji te regulativi kompromisa između europskih naroda nego u svojoj osnovnoj definiciji sugerira realističan koncept kooperativne suradnje koja vodi demokratske vlade prema ekspanziji međunarodnih veza kako bi zaštitile vlastito gospodarstvo i građane od fluktuacija na svjetskom tržištu. Drugim riječima, EU se ne temelji na specifičnim interesima, manipulaciji i konfliktu, nego na međuzavisnosti europskih zemalja u stvaranju bolje sutrašnjice. Sam koncept EU-a kao međunarodnog režima veoma je kompleksan u svojoj naravi, time da ga određuje nekoliko karakterističnih domena: načelima-normama-pravilima, supranacionalnim procedurama u odlučivanju, obvezujućim, ali ne nametnutim konvencijama te bilanciranju između kolektivnih koristi i troškova. Pojedinačna analiza navedenih komponenti mogla bi nas dovesti $u$ iskušenje prema preispitivanju implicitne značajnosti i misije EU-a time da se selektivnim promatranjem stvara lažna dihotomija između pravila i sustava odlučivanja na jednoj strani te vrijednostima kojima se teži na drugoj strani. Iščekujući 1. srpnja 2013. kao mogući da- tum ulaska Republike Hrvatske u uniju europskih naroda, mnogi ponovno vrednuju tu, za Hrvate novu, a opet i poznatu (kao dijela ex Jugoslavije), međuzavisnost koja može generirati i dobre i loše rezultate; jer kao što se rast i prosperitet mogu prelijevati iz zemlje u zemlju, tako i prelivana inflacija te nezaposlenost mogu stvoriti ograničenja u stvaranju EU-a kao unije blagostanja (welfare union), zamjenjujući time koncept države blagostanja (welfare state).

Sveučilišni udžbenik Ekonomija Europske unije nudi upravo jednu takvu revaluaciju osnovnih ideja i principa djelovanja EU-a, istodobno analizirajući ulogu Republike Hrvatske u samom procesu pristupa i ostvarivanju punopravnoga članstva u toj važnoj regionalnoj, ali i globalnoj, "ideji". Kao što i autorica ističe, problematika knjige usmjerena je prema prikazu temeljnih obilježja EU-a i principa djelovanja zajedničkih politika u segmentu gospodarstva. Naslov konceptualno sugerira sadržaj udžbenika kao materije koja opisuje mikroekonomsku, mezoekonomsku i makroekonomsku pozadinu nastanka, razvoja i perspektive EU-a u novim svjetskim uvjetima, posebice ako je razmatramo s aspekta posljedica zadnje velike svjetske krize. Naglašeni koncepti, poput globalizacije, regionalizma, konkurentnosti, tržišnoga natjecanja, zaštite potrošača i sl., daju posebnu pragmatičnu instancu udžbeniku, produbljujući osnovne ekonomske relacije danas nezaobilaznim temama, poput definiranja nacionalnih strategija i politika konkurencije, zaštite tržišnog natjecanja, ekologije, energetike, prometne politike, održivog razvoja itd. Time tekst osigurava sistematičan pregled povijesti nastanka EU-a, institucija i procedura vezanih uz njezino funkcioniranje, zajedničkih ekonomskih i socijalnih politika koje određuju buduću perspektivu razvoja unije kao i pravnu legislativu koja formira očekivanja, pa i sustav vrijednosti, "europskoga građanina" (European citizen). Udžbenik pruža nevjerojatnu dubinu analize, koja proizlazi iz autoričina dugogodišnjeg iskustva u proučavanju tematike EU-a, istodobno osigura- 
vajući predavačima i studentima prilagodbu predavanja vlastitim interesima i specifičnim poljima analize funkcioniranja unije. Ukratko, udžbenik veoma informativno i objektivno prezentira sve relevantne teme (poput gospodarske i političke suradnje, promicanja mira, slobode, demokratskih vrednota i vladavine prava, blagostanja te gospodarskoga i socijalnoga napretka) vezane uz europski identitet, koji se postiže članstvom u EU-u. U konačnici, rad po svojem formatu i sadržaju nudi kompletan i sistematičan pristup analizi, a prožet je iscrpnim informacijama i podacima uokvirenim velikim brojem tablica, slika i grafikona, koji dodatno olakšavaju razumijevanje problematike.

Udžbenik je podijeljen u 14 poglavlja, kojima prethodi predgovor te popis svih dodataka knjizi. Naslov svakoga poglavlja indikativno upućuje na problematiku koja će se analizirati, a pritom neizbježan element završetka poglavlja čini i osvrt na situaciju i/ili stadij procesa u kojemu se nalazi Republika Hrvatska u odnosu na promatranu temu. Afirmiranost teksta za potrebe studenta ponajbolje se vidi pri kraju svakoga poglavlja, gdje je kratak repetitivni sažetak plus dodatak temi, popis literature upotrijebljene $\mathrm{u}$ tom poglavlju te pitanja za ponavljanje, što ovaj udžbenik čini idealnim za učenje i utvrđivanje gradiva.

Struktura udžbenika odražava koherentnost sadržaja, međutim on se može podijeliti na tri konceptualna dijela. Prvi dio knjige govori o važnosti EU-a kao nadnacionalne europske strukture u međunarodnom okruženju, sugestivno predočujući što članstvo u uniji donosi. Prvo poglavlje, Globalizacija i regionalizam, proučava kako se nacionalni gospodarski suvereniteti gube $u$ procesu globalizacije kroz prefe- rencijalne sporazume, multilateralne kooperacije te trgovinske blokove, navezujući to s problematikom konkurentskih regionalnih blokova stvorenih u Sjevernoj Americi (NAFTA), Južnoj Americi (MERCOSUR) te Dalekom istoku (ASEAN). Drugo poglavlje, Povijest regionalnih integracija u Europi, opisuje povijest suradnje i procesa integracije započete 1951. godine između prvih šest zemalja, pet valova proširenja te institucionalne promjene koje su se preko Europske ekonomske zajednice, Jedinstvenoga tržišta, Europske zajednice i monetarne unije uokvirile $u$ današnji pojam Europske unije. Kao logičan nastavak, u trećem poglavlju, Institucije Europske unije, predstavljeni su izvori prava te osnovne institucije EU-a. Osim detaljno opisane institucionalne pozadine unije, posebnu pažnju plijeni i dodatak na kraju poglavlja, u kojemu su jasno opisane pozicije i stavovi političkih grupa u Europskom parlamentu, rangirajući ih od krajnje liberalnih Europljana do ekstremno desnih nacionalista koji se opiru daljnjem širenju europskih integracija. Fiskalni federalizam, koji je jedno od osnovnih obilježja nadnacionalne strukture EU-a, opisan je u četvrtom poglavlju, Proračun Europske unije. Naglašavajući ex ante ravnotežu financijskog okvira te nemogućnost planiranja deficita, kao i načelo solidarnosti, autorica deklarativno ocjenjuje pozitivnim financijsku disciplinu i stabilnost fiskalne situacije, jer jedino učinkovito i kontrolirano ubiranje i trošenje sredstava može pridonijeti pozitivnim trendovima rasta i razvoja i pojedine zemlje i unije u cjelini.

Drugi dio knjige, po sadržaju opsežniji, usmjeren je prema analizi "zajedničkih" politika EU-a. Peto poglavlje, Zajednička poljoprivredna politika Europske unije, proučava najstariju i troškovno najznačajniju politiku unije kroz mnogobrojne reforme koje je ona doživjela u 50-godišnjoj povijesti od osnivanja Europskoga fonda za usmjeravanje i jamstva u poljoprivredi davne 1962. godine. Šesto poglavlje proširuje pitanje zajedničkoga stava prema regionalizmu i kroz tematiku pod naslovom Regionalna politika Europske unije analizira 
povijesni razvoj i načela, instrumente i ciljeve te usmjerenja proračunskih sredstava regionalne politike EU-a. Jedna od najzanimljivijih i sigurno najaktualnijih tema obrađena je u sedmom poglavlju, Monetarna politika Europske unije. U ovom dijelu analizirana je problematika optimalnoga valutnog područja, opisan je proces uspostave monetarnoga jedinstva te Eurozone, analiziraju se iskustva zemalja koje su uvele euro kao i problemi koji u okviru trenutačne krize pogađaju Eurozonu, posebice PIGS zemlje (Portugal, Italija, Grčka i Španjolska) s aspekta stabilnosti valute i nemogućnosti servisiranja međunarodnih dugova. Iduća dva poglavlja - Industrijska politika i politika konkurencije Europske unije te Konkurentnost Europske unije - analiziraju industrijsku politiku EU-a, argumente za vođenje horizontalne i sektorske politike i perspektivu podizanja konkurentnosti EU-a kroz dvije najvažnije domene razvoja u novom tisućljeću, a to su Lisabonska strategija te Strategija "Europa 2020". Deseto poglavlje, Tržište rada $i$ socijalna politika u Europskoj uniji, govori o okviru socijalne politike $i$ tržištu rada $u$ EU-u, problematici koja se posebice intenzivirala nakon uspostave jedinstvenoga tržišta rada. Jedanaesto poglavlje, Trgovinska politika Europske unije, proučava sustav preferencijalnih sporazuma EU-a s ostalim zemljama/grupacijama u okruženju u okviru multilateralnih procesa razvoja trgovine, ali i ostalih politika koje su kanalima interesa povezane s trgovinom, primjerice politika konkurencije, vanjska politika, poljoprivredna politika i sl.

U posljednjem dijelu knjige autorica analizira međusobnu povezanost EU-a sa zemljama u okruženju koje još nisu postale zemlje članice ili se nalaze $u$ procesu pristupa. Dvanaesto poglavlje, Europska u- nija i zemlje Jugoistočne Europe (Zapadnog Balkana), promatra novouspostavljene veze EU-a s navedenim zemljama nakon proklamacije liberalnih zasada u njihovim gospodarstvima, gdje je naglasak stavljen na odnose EU-a i Republike Hrvatske od potpisivanja Sporazuma o stabilizaciji i pridruživanju pa do zatvaranja pregovora. U trinaestom poglavlju, Ostale politike Europske unije tematika se ponovno vraća analizi specifičnih zajedničkih politika EU-a koje u zadnje vrijeme dobivaju sve veće značenje, a tiču se zaštite okoliša, prometa i energetike. Posljednje, četrnaesto, poglavlje, Ostale europske integracije: EFTA i CEFTA, ukratko, gotovo dopunski, analizira djelovanje preostalih europskih integracija (koje su u svim pogledima povezane s EU-om) od njihova osnivanja do danas.

Udžbenik Ekonomija Europske unije namijenjen je $u$ prvom redu čitateljima ekonomske struke, i to studentima preddiplomskih, diplomskih te poslijediplomskih ekonomskih studija, međutim lucidnost teksta i razina informacija koje on pruža sugerira da ova knjiga može biti vrlo korisna široj i užoj javnosti (pravnicima, sociolozima, psiholozima, politolozima i sl.), odnosno svima onima koji žele razumjeti zašto je jedna od osnovnih krilatica EU-a slogan "Ujedinjeni u različitosti". To nas navodi na sljedeću opasku, koja može biti shvaćena kao cilj autorice, ali i kao kritika. Naime, knjiga - iako sadrži brojne analize te razmatra koncept EU-a s akademski prihvatljiva stajališta, a to je kritički pristup temi stvara dojam optimističnosti što ih EU donosi, prikazujući članstvo u njoj kao snažan poticaj za daljnji politički i ekonomski razvoj i starih zemalja članica i novih, među kojima je i Republika Hrvatska. U tom smislu knjiga može biti veoma sugestivnoga karaktera, no ipak se čini kako dubina ulaska u pojedinu problematiku osigurava razvoj kritičkoga razmišljanja koji je potreban studentima $u$ razumijevanju i shvaćanju materije. Time što knjiga poprima oblik udžbenika tekst je izvrsno sadržajno organiziran. Naime, sadržaj djela iznesen je pregledno i jasno u odgovarajućem slijedu - i u konceptualnom i u jezič- 
nom smislu. Nadalje, udžbenik pruža solidnu teorijsku pozadinu koja je upotpunjena aktualnim podacima o trendu kretanja socioekonomskih varijabli, što tekst u konačnici čini gotovo dominantnim izvorom objektivnih informacija o ekonomiji EU-a i perspektivi života u zajednici u kojoj se nacionalni identitet i suverenitet poistovjećuju s nadnacionalnim identitetom i pripadnošću uniji. Donoseći pregled teoretskih stavova koji se bave ovom problematikom, ali i niz zanimljivih argumenata, spoznaja i zaključaka, udžbenik pobuđuje znatiželju i čita se s uživanjem. Zato ga toplo preporučujem svima koji žele proširiti vidokrug i znanje o funkcioniranju EU-a.

Daniel Tomić

\section{doi:10.5559/di.21.3.13 \\ Geran-Marko Miletić U POTrAzI ZA DRUGIM PROSTOROM Sociologijski aspekti sekundarnog stanovanja U Hrvatskoj}

Institut društvenih znanosti Ivo Pilar, Zagreb, $2011 ., 292$ str.

U izdanju Instituta društvenih znanosti "Ivo Pilar", biblioteke Centra za urbane i ruralne studije, objavljena je knjiga Gerana-Marka Miletića U potrazi za drugim prostorom: sociologijski aspekti sekundarnog stanovanja u Hrvatskoj. Knjiga ima 292 stranice, sastoji se od uvoda, pet osnovnih poglavlja, unutar kojih je više potpoglavlja i podcjelina, zaključnog razmatranja te po- sebnih priloga s brojnim tablicama na kraju knjige. Glavna su poglavlja: 1. Uvod, 2. Teorijski okvir za analizu sekundarnog stanovanja, 3. Obrasci korištenja stanova za odmor, 4. Evolucija sekundarnog stanovanja u Hrvatskoj, 5. Anketno istraživanje - Zagrepčani u potrazi za "drugim prostorima", 6. Zaključne napomene i 7. Prilog.

U prvom, uvodnom, poglavlju autor najprije obrazlaže sam pojam sekundarno stanovanje, polazeći od termina stanovi za odmor, koji se, prema definiciji Državnog zavoda za statistiku, isključivo rabe za odmor i rekreaciju - bilo povremeno ili više mjeseci u godini. Budući da je najveća gustoća sekundarnih stanova na hrvatskom priobalju, za koje Miletić drži kako je danas zasigurno najvredniji nacionalni resurs, razvoj sekundarnoga stanovanja stvara i određene socijalne, ekonomske i prostorne promjene, a siguran je i nastavak rasta broja stambenih objekata namijenjenih odmoru u Hrvatskoj. Samim time intenzivirat će se i navedene promjene, pa autor zaključuje kako širenje sekundarnih stanova postaje jedna od važnijih tema u promišljanju daljnjeg razvoja Hrvatske. Stoga je i jedan od glavnih ciljeva ove analize i istraživanja, pokušati odgovoriti na dva temeljna pitanja o naznačenoj pojavi: prvo je pitanje o ishodištima i implikacijama širenja sekundarnoga stanovanja u Republici Hrvatskoj, a drugo je o prirodi takva stanovanja na više adresa.

Drugo poglavlje, Teorijski okvir za analizu sekundarnog stanovanja, podijeljeno je na tri potpoglavlja: Stanovanje $i$ dihotomija primarno/sekundarno, Sličnosti i razlike između turizma i sekundarnog stanovanja, Skica za hipotetski model sekundarnog stanovanja. U prvom potpoglavlju autor razmatra osnovne pristupe $\mathrm{u}$ razumijevanju stambene problematike i analizira pitanje kada stanovanje prestaje biti primarno i postaje sekundarno. Polazeći od činjenice kako je (primarno) stanovanje jedna od temeljnih antropoloških kategorija kroz koju se na određen način odražava ljudska težnja za stvaranjem zavičaja, ali i potreba za individualizacijom, autor ističe kako vlastiti stam- 